\title{
Expression of EBV Encoded viral RNA 1,2 and anti-inflammatory Cytokine (interleukin-10) in FFPE lymphoma specimens: a preliminary study for diagnostic implication in Pakistan
}

Taimoor I Sheikh ${ }^{*+}$ and Ishtiaq Qadri ${ }^{\dagger}$

\begin{abstract}
Background: Epstein Barr Virus (EBV) plays a significant role as a cofactor in the process of tumorigenesis and has consistently been associated with a variety of malignancies. EBV encoded RNAs (EBER1 and EBER2) are the most abundant viral transcripts in latently EBV-infected cells and their role in viral infection is still unclear. Formalin Fixed Paraffin Embedded (FFPE) tissues of surgically removed carcinoma biopsies are widely available form but have never been exploited for expressional studies previously in Pakistan. Immunohistochemistry (IHC) and in situ hybridization (ISH) in FFPE biopsy tissues remains the gold standard for proving EBV relationship in a histopathological lesion but their reagents associated limitations confines their reliability in some applications. Recently introduced targeted drug delivery systems induce viral lytic gene expression and therefore require more sensitive method to quantify viral as well as cellular gene expression.

Methods: Eight (8) lymphoma samples were screened to detect the EBV genome. Qualitative and quantitative expression of EBV Encoded RNAs (EBER1, EBER2) and anti-inflammatory cytokine (interleukin-10) in FFPE EBV positive lymphoma tissue samples were then analysed by using Reverse transcriptase Polymerase Chain Reaction (RT-PCR) and Real Time Polymerase Chain Reaction (qRT-PCR), respectively.

Results: In this study we have successfully quantified elevated expressional levels of both cellular and viral transcripts, namely EBER1, EBER2 and anti-inflammatory cytokine (IL-10) in the FFPE Burkitt's lymphoma (BL) specimens of Pakistani origin.

Conclusions: These results indicate that FFPE samples may retain viral as well as cellular RNA expression information at detectable level. To our knowledge, this is first study which represents elevated expressional levels of EBER1, EBER2 and IL-10 in FFPE tissue samples of Burkitt's lymphoma in Pakistan. These observations will potentially improve current lacunas in clinical as well as diagnostic practices in Pakistan and can be further exploited to develop new strategies for studying cellular and/or viral gene expression.
\end{abstract}

\section{Background}

Epstein-Barr virus (EBV) [1] is a ubiquitous human $\gamma$-herpes virus infecting more than $90 \%$ of the population worldwide [2] and plays a significant role as a cofactor in the process of tumorogenesis. It has consistently been associated with a variety of malignancies including

\footnotetext{
* Correspondence: islamtaimoor@yahoo.com

+ Contributed equally

NUST Center of Virology and Immunology, National University of Sciences \& Technology, Sector H-12 Islamabad 44000, Pakistan
}

endemic Burkitt's lymphoma (BL) [1,2], nasopharyngeal carcinoma [3,4], T-cell lymphoma, Pyothorax-associated or methotrexate-associated B-cell lymphoma, Primary effusion lymphoma, gastric carcinoma [5], EBV associated hemophagocytic syndrome and approximately $50 \%$ of Hodgkin's diseases. Moreover it has been associated with different types of lymphoproliferative diseases especially in immunocompromised patients [6]. In immunocompromised patients with impaired cell mediated immunity, acute EBV infection is associated with the development of
C Biomed Central

(c) 2011 Sheikh and Qadri; licensee BioMed Central Ltd. This is an Open Access article distributed under the terms of the Creative Commons Attribution License (http://creativecommons.org/licenses/by/2.0), which permits unrestricted use, distribution, and reproduction in any medium, provided the original work is properly cited. 
lymphoproliferative disease, with mortality rates between 50-80\%. In addition to that, recipients of solid organ transplants, the incidence of post transplant lymphoproliferative disease (PTLD) ranges from 1\% to 15\% [7]. Prevalence of EBV in Pakistani Burkitt's lymphoma patients is $80 \%$ which is significantly higher than in BL in North America [8].

EBV replicates in the epithelial cells of the mouth, tongue, salivary glands, and oral cavity and then it spread into the B-cells which are the main host cell type for its latent infection [9]. Upon entry into B cell, the EBV proteins are expressed in a cascade manner. Every EBV-transformed cell carries multiple extrachromosomal copies of the viral episome and constitutively expresses a limited set of viral gene products referred to as latent proteins, which comprise of: Six (6) EBV nuclear antigens (EBNAs 1, 2, 3A, 3B, $3 C$ and -LP) [9-11], three latent membrane proteins (LMPs 1, 2A and 2B) and transcripts from the BamHIA region of the viral genome namely BART transcripts $[11,12]$. In addition to the latent proteins, EBV-transformed cell also show abundant expression of the small, non-polyadenylated non-coding RNAs, EBER1 and EBER2. This pattern of latent EBV gene expression, which appears to be activated only in Burkitt's lymphoma, is referred to as 'latency I' [9-13]. Interleukin-10 (IL-10) an anti-inflammatory cytokine (also known as human Cytokine Synthesis Inhibitory Factor (CSIF)), is known to be an important regulator in cell transformation [14]. $\mathrm{EBV}^{+}$ (positive) Burkitt's lymphoma (BL) cells express high level of IL-10 as compared to the $\mathrm{EBV}^{-}$(negative) BL cell lines [15]. On the other hand, the expressional levels of IL-10 are extremely low and/or negligible in normal tumour cell lines $[15,16]$. Approximately 10 fold increased expression of the IL-10 in Burkitt's lymphoma cell lines is reported [16]. These elevated levels of EBER and IL-10 have also been known to increase cell's tumorigenicity $[17,18]$. This expression profile could be used as power full tool in the expressional profiling studies as well as relative quantification of EBERs in the tissue samples.

For tissue preservation, formalin fixation followed by paraffin wax embedding is mostly used to maintain the morphological features of the original tissue [19]. The Formalin Fixed and Paraffin Embedded (FFPE) tissues are used in various immunohistochemistry (IHC) techniques for localizing Epstein-Barr viral nucleic acid and/or protein to the tumour cells. Previously EBER in-situ hybridization (ISH) was considered as the most excellent test for detection and localization of latent EBV in tissue samples [20,21]. Other techniques including automated EBER ISH and automated LMP-1 IHC with increased sensitivity and specificity have recently became useful diagnosis tool for EBV related diseases [22-24].

ISH reagents associated limitations like limited target site accessibility and capacity to penetrate into whole mount tissue specimens confines its reliability [25]. Although, both techniques (fluorescent in-situ hybridization (FISH) and reverse transcriptase polymerase chain reaction (RT-PCR)) have inevitable advantages in the field of diagnostics but comparative evidence of more target specificity and sensitivity of RT-PCR for the detection of minimal residual disease in long-term monitoring of patients has increased its importance in some applications [26]. In addition to that quantitative real time PCR which has ability to detect as low as two fold changes in the gene expression, is rapidly replacing immunological assays $[27,28]$. Numerous therapeutic agents aiming EBV associated tumour regression are beginning to emerge $[29,30]$. These targeted drug delivery systems induce viral lytic gene expression $[30,31]$ and therefore, require more sensitive quantitative analysis of viral as well as cellular gene expression to monitor the effect of these therapeutic treatments.

This study was aimed to develop a precise Real time PCR based laboratory methodology to detect and quantify EBV encoded RNAs in FFPE Burkit's lymphoma samples of Pakistani origin. Furthermore, anti-inflammatory cytokine (IL-10) expression in $\mathrm{EBV}^{+}$(positive) samples were characterized to indicate its relevance with viral persistence in tumour cells. These studies will introduce novel potential biomarkers as well as new insight in the current diagnostic trends of Pakistan.

\section{Methods}

\section{Sample Collection and Cell Culture}

In total eight (8) lymphoma samples were included in this study. The sampling was conducted at Pakistan Institute of Medical Sciences (PIMS), for routine histopathological examination. Formalin Fixation and Paraffin Embedding (FFPE) procedures were then carefully performed [32-35] on lymphoma samples individually, under sterile conditions. After histopathological examination three (3) samples were classified as Burkitt's lymphoma (BL) and five (5) as non-Hodgkin lymphomas (NHLs).

EBV transformed B95-8 cell line (Kindly provided by Dr. Sharof Tugizov Department of Medicine, University of California, San Francisco, California USA) were maintained in RPMI 1640 supplemented with $10 \%$ fetal bovine serum (FBS), 1\% L-glutamine, and 1\% penicillinstreptomycin (all from Gibco, Basel, Switzerland).

\section{Nucleic Acid Extraction and Purifications}

Approximately $4 \times 20 \mu \mathrm{m}$ sections of selected samples were taken for nucleic acid extraction and purification. Genomic DNA was purified from Formalin-fixed Paraffin embedded tissue sections by using QIAamp DNA FFPE Tissue Kit (Qiagen).

Total RNA of the positive samples was extracted by using PureLink ${ }^{\mathrm{TM}}$ FFPE Total RNA Isolation Kit 
(Invitrogen Carlsbed, CA U.S.A) according to manufacturer instructions. All samples were treated with DNase I Amplification Grade (Invitrogen Carlsbed, CA U.S.A) to eliminate DNA contaminations.

\section{Amplification and Detection}

Before EBV specific amplifications, all DNA samples were tested with primers to amplify a fragment of the human $\beta$ globin Genes in order to ensure DNA integrity. Initially, nested PCR based screening for EBV presence of all lymphoma samples were carried out by targeting genomic DNA of EBNA1 as recommended by Bagan JV et al, 2008 [36].

Qualitative PCR of EBV positive samples were performed in total volume of $20 \mathrm{ul}$ containing final concentrations of $100 \mathrm{ng}$ genomic DNA, Taq Buffer with $\mathrm{KCl}$; 2.5 units of Taq DNA polymerase, $2 \mathrm{mM}$ dNTPs, 1.5 $\mathrm{mM} \mathrm{MgCl} 2$ final concentration (Fermentas). In the first round of amplification, primers for EBER1 and EBER2 (Table 1) aimed at amplifying a fragment of $166 \mathrm{bp}$ and $172 \mathrm{bp}$, respectively.

\section{Quantitative Real time PCR (qRT-PCR)}

Quantitative Real time PCR (qRT-PCR) of 10 ul of Total RNA template (50 ng) of $\mathrm{EBV}^{+}$(positive) and $\mathrm{EBV}^{-}$(negative) samples were used to amplify EBER 1/EBER 2 and IL-10 aimed primers (Table 1). Thermocycling was performed at $95^{\circ} \mathrm{C}$ for 3 minutes, followed by 40 cycles at $94^{\circ}$ $\mathrm{C}$ for $30 \mathrm{~s}, 54^{\circ} \mathrm{C}$ for $30 \mathrm{~s}$, and $72^{\circ} \mathrm{C}$ for $40 \mathrm{~s}$ to measure the fluorescence signal. Quantitative analyses of the data were carried out using 7300 system SDS software v1.4 (Applied Biosystems, USA). Reaction concentrations and conditions were adjusted according to the manual instructions of SuperScript ${ }^{\circledR}$ III Platinum ${ }^{\circledR}$ SYBR $^{\circledR}$ Green One-Step qRTPCR Kit (Invitrogen Carlsbed, CA, U.S.A). Equal quantity of RNA from B95-8 cell line (Positive control) and $\mathrm{EBV}^{-}$ tissue sample (Negative control) were used. All experiments were done in triplicate.

\section{Purification and Sequencing}

The amplified product was purified by using PureLink ${ }^{\mathrm{TM}}$ Gel Extraction Kit (Invitrogen Carlsbed, CA U.S.A) according to the manufacturer's instructions. The purified product was sequenced by using Genetic Analysis System Beckman Coulter (CEQ-8000 USA). These sequences were published in Genbank, EMBL and DDBJ [Accession Number: GU205106 \&GU205107].

\section{Date Analysis}

In a real time PCR assay Ct (cycle threshold) is defined as the number of cycles required by fluorescent signals to cross the threshold. Ct levels are inversely proportional to the quantity of target nucleic acid in the sample $[37,38]$.

In these experiments, the linear rates of expressions of EBER1, EBER2 and IL-10 were calculated by dividing the threshold (0.10) with respective mean CT values of $\mathrm{EBV}^{+}$patients.

\section{Results and Discussions}

Epstein Barr Virus (EBV) play significantly as a cofactor in the process of viral induced oncogenesis and associated with a larger range of malignancies [2-5]. Here, we have screened eight (8) FFPE lymphoma samples of for the presence of EBV nuclear antigen (EBNA1) (Figure 1). In addition to that, EBV encoded RNAs (EBER1 and EBER2) are the most abundant viral transcripts in latently EBV-infected cells $[12,13]$ and their role in viral infection is still unclear. In this study, we have developed a qualitative reverse transcriptase (RT-PCR) based assay system (Figure 2) to detect genomic fragments of EBER1 and 2 from Formalin Fixed Paraffin Embedded (FFPE) tissue sample. The FFPE sections are most broadly available form of lymphoma tissues in Pakistan.

Viral gene expression based studies provide a better chance to understand virally induced lymphomas at molecular level which leads to the discoveries of potential biomarkers and therapeutic agents [39-41]. Several drugs involved in tumour degeneration require knowledge of change in gene expression in diseased tissues [30,31]. Furthermore, FFPE samples have not yet been analytically investigated with respect to viral gene expression in Pakistan. We have for the first time purified, amplified (Figure 3) and sequenced [Genbank, EMBL, DDBJ Accession Number: GU205106 \&GU205107] viral RNAs from the FFPE Burkit's lymphoma tissue samples. These results

Table 1 Specification of Primers used in RT-PCR and qRT-PCR Experiments

\begin{tabular}{|c|c|c|c|}
\hline S. No. & Target Gene & Primer Name & 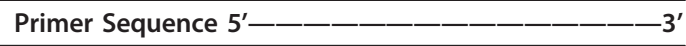 \\
\hline 1) & EBV encoded RNA 1 (EBER1) & $\begin{array}{l}\text { EB1 (Forward) } \\
\text { EB1 (Reverse) }\end{array}$ & $\begin{array}{l}\text { 5'- AGGACCTACGCTGCCCTAGA -3' } \\
\text { 5'- AAAACATGCGGACCACCAGCTGG -3' }\end{array}$ \\
\hline 2) & EBV encoded RNA 2 (EBER2) & $\begin{array}{l}\text { EB2 (Forward) } \\
\text { EB2 (Reverse) }\end{array}$ & $\begin{array}{l}\text { 5'- AGGACAGCCGTTGCCCTAGTG -3' } \\
\text { 5'- TAGCGGACAAGCCGAATACCCT -3' }\end{array}$ \\
\hline 3) & Interleukin 10 (IL10), mRNA & $\begin{array}{l}\text { IL-10 (Forward) } \\
\text { IL-10 (Reverse) }\end{array}$ & $\begin{array}{l}\text { 5'- ATGCACAGCTCAGCACTGCTCTG -3' } \\
\text { 5'- GGAAGAAATCGATGACAGCGCCG -3' }\end{array}$ \\
\hline 4) & Glyceraldehyde-3-Phosphate Dehydrogenase (GAPDH), mRNA & $\begin{array}{l}\text { GAP (Forward) } \\
\text { GAP (Reverse) }\end{array}$ & $\begin{array}{l}\text { 5'- CAAGGTCATCCATGACAACTTGG -3' } \\
5^{\prime}-\text { GTCCACCACCCTGTTGCTGTAG -3' }\end{array}$ \\
\hline
\end{tabular}




\section{FFPE Lymphoma Samples}

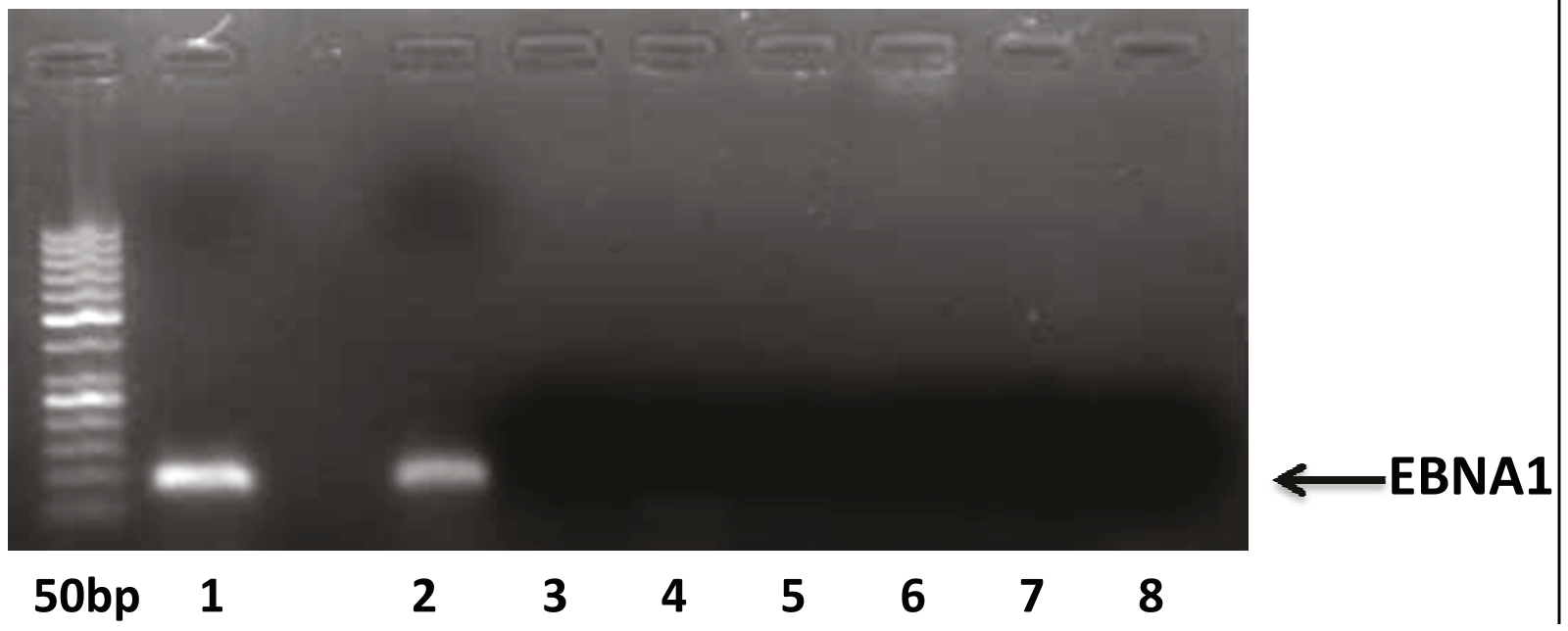

Figure 1 Results of agarose Gel Electrophoresis of EBNA 1 genomic DNA (left-to-right): Lane 1 shows the 50 bp DNA ladder, Lane 2-3 represents the EBNA1 positive Burkitt's lymphoma samples (100 bp Nested PCR amplified product), Lane 4 represents EBNA1 Negative Burkitt's lymphoma (BL) samples, Lane 5,6,7,8 represents EBNA1 Negative non-Hodgkin lymphomas (NHLs) samples.

positively suggest the use of FFPE samples for research, more prominently in viral RNA profiling studies. In addition to that, we have also developed a real time PCR based assay in which a novel comparison of viral and cellular RNA is illustrated (Figure 4). This was done on the bases of an observation that expression of IL-10 mRNA was negligibly low in normal EBV negative lymphoma tissues [14-17]. We have successfully quantified

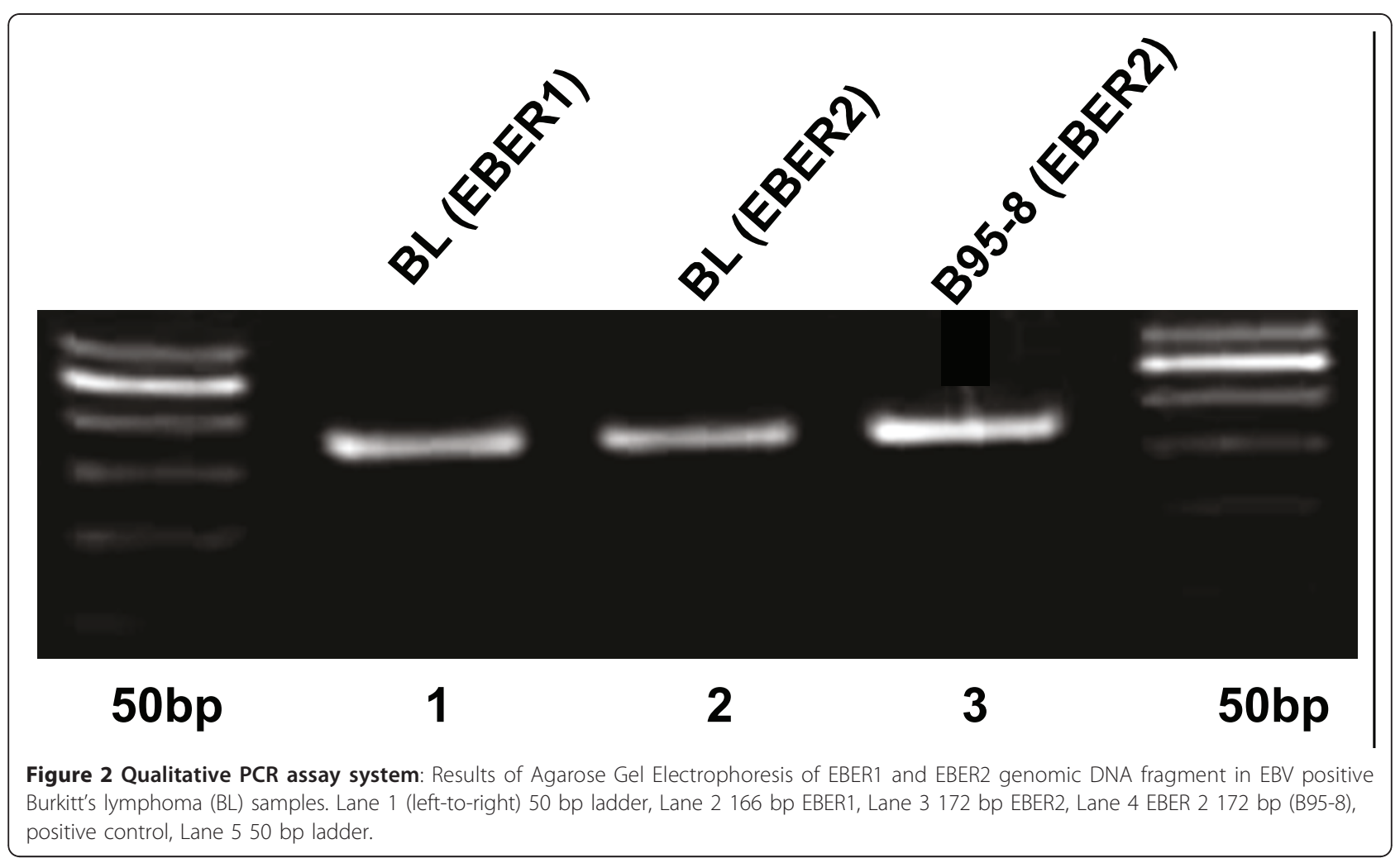




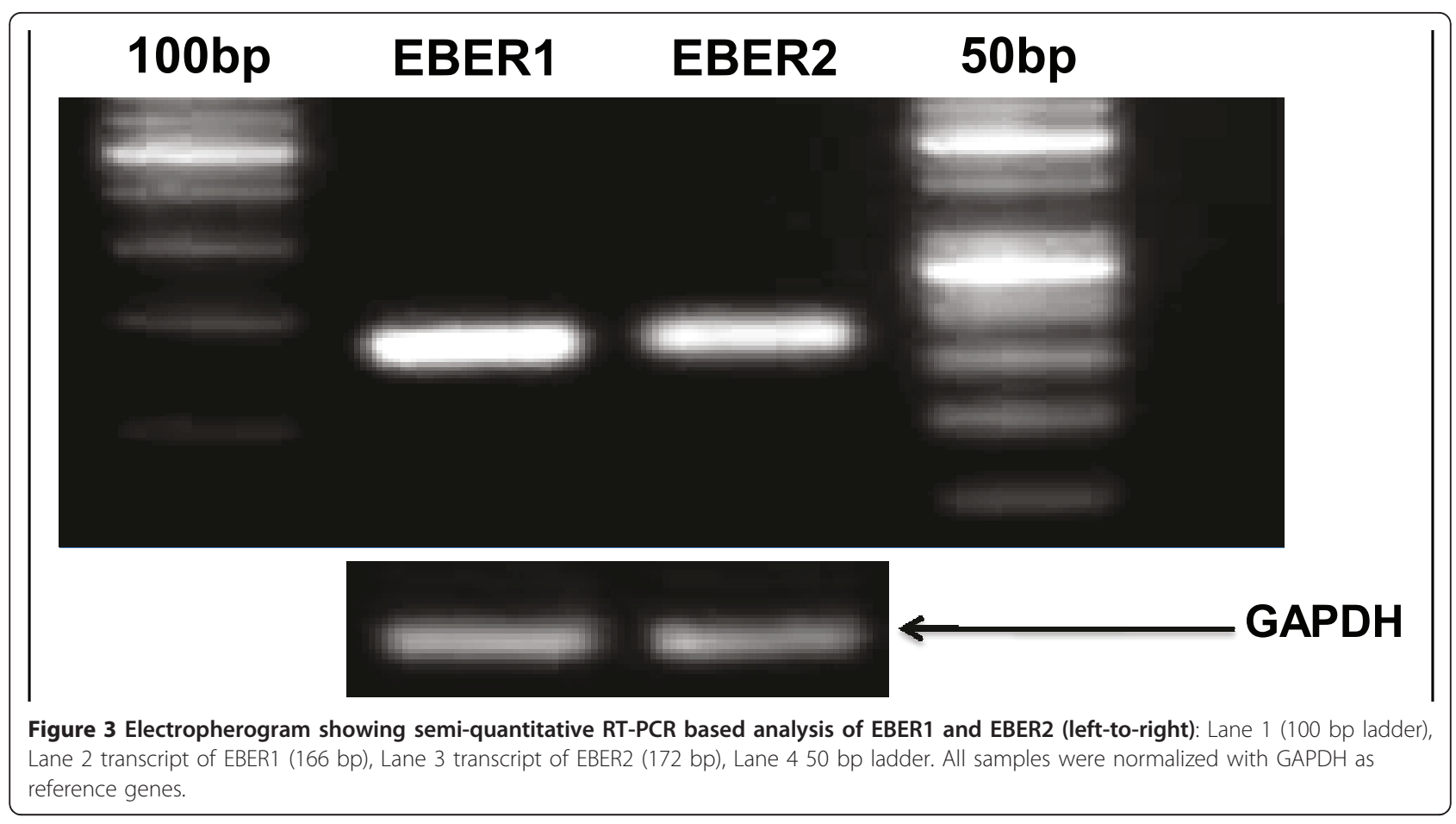

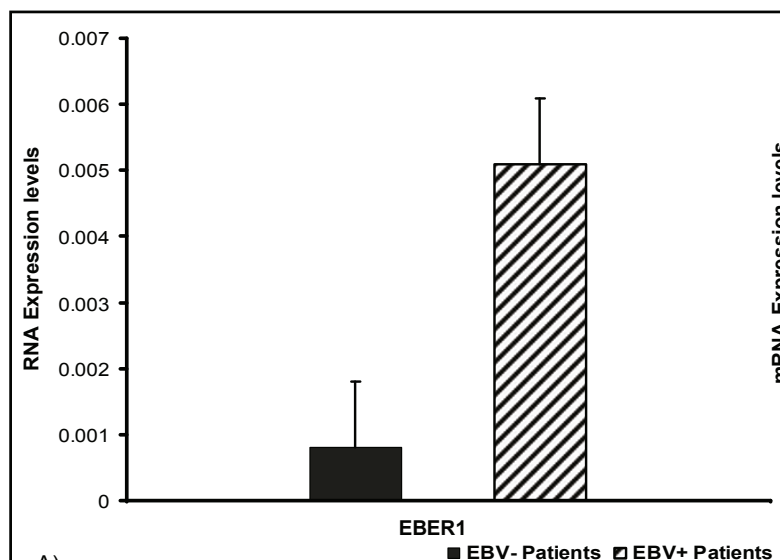

A)

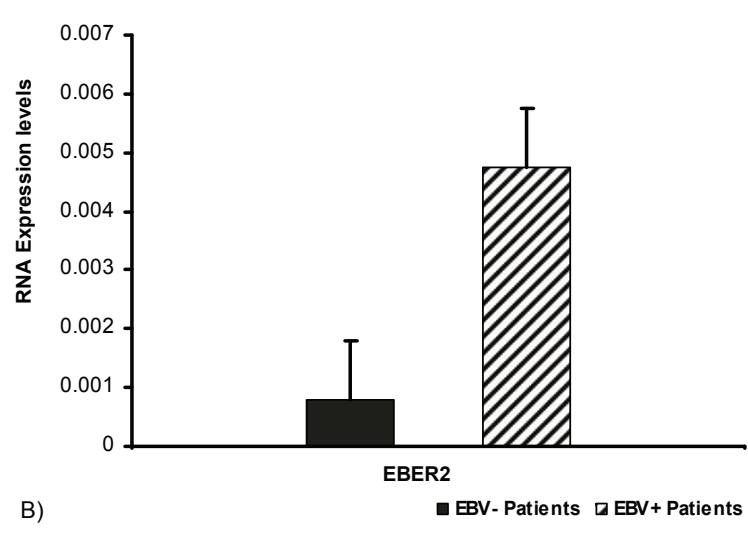

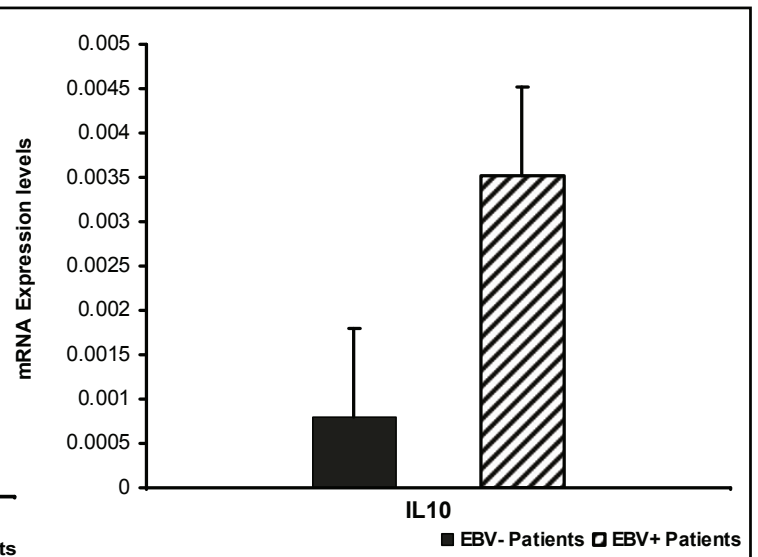

C)

Figure 4 Real-time PCR based Quantitative analysis of EBER1, EBER2 and IL-10 transcripts: Real-time PCR was performed to determine the expression status of IL-10, EBER1 and EBER2. GAPDH was used as a reference gene to normalize expression of all samples. Expression levels of EBER1 (A), EBER2 (B) and IL-10(C) in EBV infected Burkitt's lymphoma samples were quantified and compared to uninfected samples as negative controls. Data are shown after log transformation. 


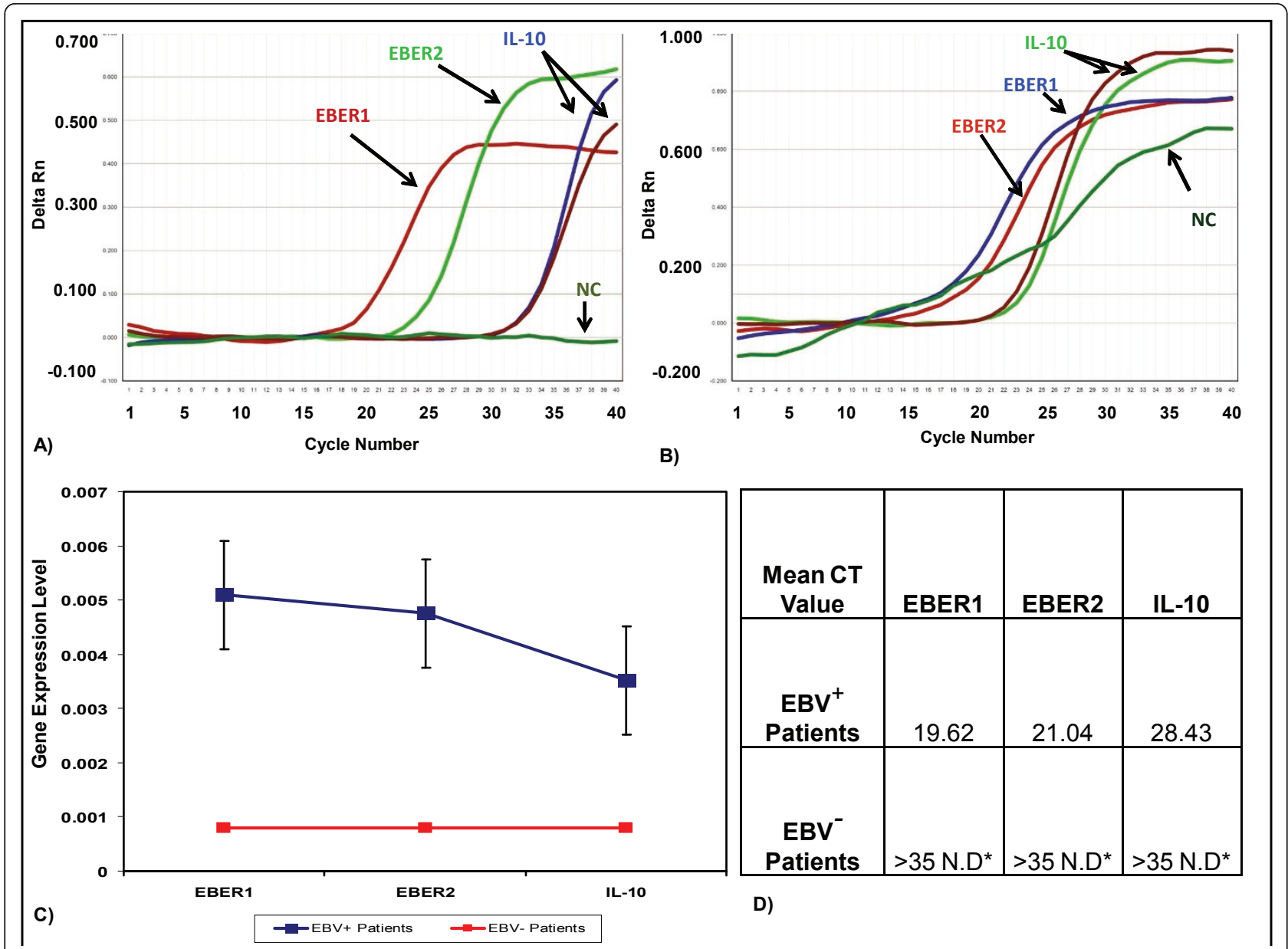

Figure 5 qRT-PCR Data analysis: Delta Rn vs Cycle (A, B): Real-time PCR amplification plot showing EBER1, EBER2 and IL-10 targets in EBV ${ }^{+}$ (positive) tumor sample in comparison with EBV Negative control sample analyzed at 0.1 threshold. Successful amplifications are shown, with absence of amplification of mismatched templates. (C) Relative Expression rate of EBER1, EBER2 and IL-10 were calculated by dividing the total threshold (0.10) with mean CT value of each sample.(D) Grid representation of specificity showing mean CT values for on-target CDNA amplification for all EBV ${ }^{+}$(positive) specimens. Note the absence of nonspecific amplification. N.D* $=$Not Detected.

and reported elevated level of IL-10 mRNA and EBV encoded viral RNAs in comparison with normal EBV subjects (Figure 5). These observations can be further used to develop precise laboratory techniques with increased reliability.

\section{Conclusions}

Expression of both viral RNA and cellular RNA are significantly high, in comparison with normal $\mathrm{EBV}^{-}$(negative) lymphoma tissues. These results suggested that RNA isolated from FFPE samples preserve the majority of the characteristic expression. In addition to that elevated expression of anti-inflammatory cytokine (IL-10) was observed in the $\mathrm{EBV}^{+}$(positive) samples in comparison with $\mathrm{EBV}^{-}$samples (undetectable or negligibly low levels of expression) which indicate its relevance with viral persistence in EBV transformed tumour cells. These studies will open novel avenues to study cellular and/or viral gene expression and will introduce new biomarkers and strategies to improve clinical as well as diagnostic practices in Pakistan.

\section{Acknowledgements}

We thank Dr. Sharof Tugizov Department of Medicine, University of California, San Francisco, California USA for providing us B95-8 cell line and National University of Sciences and Technology (NUST), Sector $\mathrm{H}-12$ Islamabad Pakistan, for proving us facilities for this research work. This work was funded by the Higher Education Commission of Pakistan (HEC, R\&D Grant Number 20-829/R\&D/2006.

We appreciate help of Dr. Jamil, RCMS NUST in Real time PCR Data analysis.

\section{Authors' contributions}

TIS have contributed to the conception, design, acquisition, analysis and interpretation of data and have been involved in drafting the manuscript as well as revising it critically for important intellectual content to be published and have given final approval of the version to be published.

IQ has contributed to the critical revision of important intellectual content and has given final approval of the version to be published as well as provided supervision during this work. 


\section{Competing interests}

The authors declare that they have no competing interests.

Received: 24 March 2011 Accepted: 27 July 2011

Published: 27 July 2011

\section{References}

1. Epstein MA, Achong BG, Barr YM: Virus particles in cultured lymphoblasts from Burkitt's lymphoma. The Lancet 1964, 1:702-703.

2. zur Hausen A, Brink AA, Craanen ME, Middeldorp JM, Meijer CJ, van den Brule AJ: Unique transcription pattern of Epstein-Barr virus (EBV) in EBVcarrying gastric adenocarcinomas: expression of the transforming BARF1 gene. Cancer Res 2000, 60:2745-2748.

3. Judde JG, Spangler G, Magrath I, Bhatia K: Use of Epstein Barr virus nuclear antigen-1 in targeted therapy of EBV-associated neoplasia. Hum Gene Ther 1996, 7:647-653.

4. Chang YS, Tyan YS, Liu ST, Tsai MS, Pao CC: Detection of Epstein-Barr virus DNA sequences in nasopharyngeal carcinoma cells by enzymatic DNA amplification. J Clin Microbiol 1990, 28:2398-2402.

5. Suzushima H, Asou N, Fujimoto T, Nishimura S, Okubo H, Yamasaki H, Osato M, Matsuoka M, Tsukamoto A, Takai K, Kawano F, Takatsuki K: Lack of the expression of EBNA-2 and LMP-1 in T-cell neoplasms possessing Epstein-Barr virus. Blood 1995, 85:480-486.

6. Carlos VP, Fung JJ, Nalesnik MA, Kieff E, Green M, Gores G, Habermann TM, Wiesner RH, Swinnen L, Woodle ES, Bromberg JS: Epstein-barr virusInduced Posttransplant Lymphoproliferative disorders. Transplantation 1999, 68:1517-1525.

7. Carlos VP, Fung JJ, Nalesnik MA, Kieff E, Green M, Gores G, Habermann TM, Wiesner R, Swinnen LJ, Woodle ES, Bromberg JS: Epstein Barr VirusInduced Posttransplant Lymphoproliferative Disorders (ptld). Transplantation 1999, 68:1517-1525.

8. Mansoor A, Stevenson MS, Li RZ, Frekko K, Weiss W, Ahmad M, Khan AH, Mushtaq S, Saleem M, Raffeld M, Kingma DW, Jaffe ES: Prevalence of Epstein-Barr viral sequences and EBV LMP1 oncogene deletions in Burkitt's lymphoma from Pakistan: epidemiological correlations. Hum Pathol 1997, 28:283-288.

9. Lawrence SY, Rickinson AB: Epstein-Barr Virus: 40 Years On. Nature Reviews Cancer 2004, 4:757-768.

10. Rowe M, Rowe DT, Gregory CD, Young LS, Farrell PJ, Rupani H, Rickinson AB: Differences in B cell growth phenotype reflect novel patterns of Epstein-Barr virus latent gene expression in Burkitt's lymphoma cells. EMBO J 1987, 6:2743-2751.

11. Wang F, Gregory C, Sample C, Rowe M, Liebowitz D, Murray R, Rickinson A, Kieff E: Epstein-Barr virus latent membrane protein (LMP1) and nuclear proteins 2 and $3 C$ are effectors of phenotypic changes in $B$ lymphocytes: EBNA-2 and LMP1 cooperatively induce CD23. J Virol 1990, 64:2309-2318.

12. Lawrence SY, Murray PG: Epstein-Barr virus and oncogenesis: from latent genes to tumours. Oncogene 2003, 22:5108-5121.

13. Takada K, Nanbo A: The role of EBERs in oncogenesis. Cancer Biology 2001, 11:461-467.

14. Kube D, Platzer $\mathrm{C}$, von Knethen $\mathrm{A}$, Straub $\mathrm{H}$, Bohlen $\mathrm{H}$, Hafner M, Tesch $\mathrm{H}$ : Isolation of the humen interleukin 10 promoter. Characterization of the promoter activity in Burkitt's lymphoma cell lines. Cytokine 1995, 7:1-7.

15. Norihiko K, Goto M, Kurozumi K, Maruo S, Fukayama M, Naoe T, Yasukawa M, Hino K, Suzuki T, Todo S, Takada K: Epstein \pm Barr virusencoded poly $(A) \pm$ RNA supports Burkitt's lymphoma growth through interleukin-10 induction. The EMBO Journal 2000, 19:6742-6750.

16. Vockerodt M, Haier B, Buttgereit $P$, Tesch H, Kube D: The Epstein \pm Barr Virus Latent Membrane Protein 1 Induces Interleukin-10 in Burkitt's Lymphoma Cells but Not in Hodgkin's Cells Involving the p38/SAPK2 Pathway. Virology 2001, 280:183-198.

17. Samanta M, Iwakiri D, Takada K: Epstein-Barr virus-encoded small RNA induces IL-10 through RIG-I-mediated IRF-3 signaling. Oncogene 2008, 27:4150-4160.

18. Fok V, Friend K, Steitz JA: Epstein-Barr virus noncoding RNAs are confined to the nucleus, whereas their partner, the human La protein, undergoes nucleocytoplasmic shuttling. The Journal of Cell Biology 2006, 173:319-325.

19. Lewis F, Maughan NJ, Smith V, Hillan K, Quirke P: Unlocking the archivegene expression in paraffin-embedded tissue. J Pathol 2001, 195:66-71.
20. Gulley ML: Molecular diagnosis of Epstein-Barr virus-related diseases. J Mol Diagn 2001, 3:1-10.

21. Ambinder RF, Mann RB: Detection and characterization of Epstein-Barr virus in clinical specimens. Am J Pathol 1994, 145:239-252.

22. Fanaian NK, Cohen C, Waldrop S, Wang J, Shehata BM: Epstein-Barr virus (EBV)-encoded RNA: automated in-situ hybridization (ISH) compared with manual ISH and immunohistochemistry for detection of EBV in pediatric lymphoproliferative disorders. Pediatr Dev Pathol 2009, 3:195-199.

23. Margaret LG, Glaser SL, Craig FE, Borowitz M, Mann RB, Shema SJ, Ambinder RF: Guidelines for Interpreting EBER In Situ Hybridization and LMP1 Immunohistochemical Tests for Detecting Epstein-Barr Virus in Hodgkin Lymphoma. Am J Clin Pathol 2002, 117:259-267.

24. Vera-Sempere FJ, Burgos JS, Botella MS, Cordoba J, Gobernado M: Immunohistochemical Expression of Epstein-Barr Virus-encoded Latent Membrane Protein (LMP-1) in Paraffin Sections of EBV-associated Nasopharyngeal Carcinoma in Spanish Patients. Oral Oncol, EurJ Cancer 1996, , 32B: 163-168.

25. Smith A, Zhang J, Guay D, Quint E, Johnson A, Akimenko MA: Gene Expression Analysis on Sections of Zebrafish Regenerating Fins Reveals Limitations in the Whole-Mount In Situ Hybridization Method. Developmental Dynamics 2008, 237:417-425.

26. Polampalli S, Choughule A, Prabhash K, Amare P, Baisane C, Kabre S, Mahadik S, Shinde S, Nair R, Banavali S: Role of RT-PCR and FISH in diagnosis and monitoring of acute promyelocytic leukemia. Indian Journal of Cancer 2011, 48:60-67.

27. Lorenzo D, Lombardi A, Vecchi ED, Giuliani G, Bartolone R, Gismondo MR: Comparison of nested PCR and real time PCR of Herpesvirus infections of central nervous system in HIV patients. BMC Infectious Diseases 2004, 4:55.

28. Ruiz G, Penña P, de Ory F, Echevarría JE: Comparison of Commercial RealTime PCR Assays for Quantification of Epstein-Barr Virus DNA. Journal of Clinical Microbiology 2005, 43:2053-2057.

29. Jabbour E, Cortes JE, Ghanem H, O'Brien S, Kantarjian HM: Targeted therapy in chronic myeloid leukemia. Expert Rev Anticancer Ther 2008, 8:99-110.

30. De-Xue F, Yvette $T$, Jianmeng $C$, Catherine AF, James JF, Ja-Mun C, Robert FH, Masashi F, George S, Jeanne K, Martin GP, Richard FA: Bortezomib-induced enzyme-targeted radiation therapy in herpesvirusassociated tumors. Nature Medicine 2008, 14:1118-1122.

31. De-Xue F, Yvette $C T$, Jianmeng $C$, Catherine $A F$, James JF, Victor $L$, JaMun C, Richard FA, Martin GP: Virus-Associated Tumor Imaging by Induction of Viral Gene Expression. Clin Cancer Res 2007, 13:1453-1458.

32. von Ahlfen $S$, Andreas M, Bendrat K, Schlumpberger KM: Determinants of RNA Quality from FFPE Samples. PLOS ONE 2007, 2:e1261.

33. Masuda N, Ohnishi T, Kawamoto S, Monden M, Okubo K: Analysis of chemical modification of RNA from formalin-fixed samples and optimization of molecular biology applications for such samples. Nucleic Acids Res 1999, 27:4436-4443.

34. Bresters D, Schipper MEl, Reesink HW, Boeser-Nunnink BDM, Cuypers HTM: The Duration of Fixation Influences the Yield of HCV cDNA-PCR Products from Formalin-Fixed, Paraffin-Embedded Tissue. J Virol Methods 1994, 48:267-272.

35. Macabeo-Ong M, Ginzinger DG, Dekker N, McMillan A, Regezi JA, Wong DT, Jordan RC: Effect of duration of fixation on quantitative reverse transcription polymerase chain reaction analyses. Mod Pathol 2002, 15:979-987.

36. Bagan JV, Jiménez Y, Murillo J, Poveda R, Diaz JM, Gavaldá C, Margaix M, Scully C, Alberola TM, Puente MT, Alonso MP: Epstein-Barr virus in oral proliferative verrucous leukoplakia and squamous cell carcinoma: A preliminary study. Med Oral Patol Oral Cir Bucal 2008, 13:110-3.

37. Real-time PCR: Understanding $C_{t}$. [http://www3.appliedbiosystems.com/ cms/groups/mcb_marketing/documents/generaldocuments/cms_053906. pdf].

38. Applied Biosystems 7300/7500 Fast Real-Time PCR System Standard Curve Experiments: Getting started guide. P.N. 4387779 Rev. C. [http:// www3.appliedbiosystems.com/cms/groups/mcb_support/documents/ generaldocuments/cms_050329.pdf].

39. Lewis RS, Ward AC: Stat5 as a diagnostic marker for leukemia. Expert Rev Mol Diagn 2008, 8:73-82.

40. Carella AM, Lerma E: Imatinib mesylate in chronic myeloid leukemia. Curr Stem Cell Res Ther 2007, 2:249-51. 
41. Pal SK, Pegram M: HER2 targeted therapy in breast cancer...beyond Herceptin. Rev Endocr Metab Disord 2007, 8:269-77.

doi:10.1186/1746-1596-6-70

Cite this article as: Sheikh and Qadri: Expression of EBV Encoded viral

RNA 1, 2 and anti-inflammatory Cytokine (interleukin-10) in FFPE

lymphoma specimens: a preliminary study for diagnostic implication in

Pakistan. Diagnostic Pathology 2011 6:70.

Submit your next manuscript to BioMed Central and take full advantage of:

- Convenient online submission

- Thorough peer review

- No space constraints or color figure charges

- Immediate publication on acceptance

- Inclusion in PubMed, CAS, Scopus and Google Scholar

- Research which is freely available for redistribution

Submit your manuscript at 